\title{
Prevalence and Determinant Factors of Stunting, Wasting and Underweight Among School Age Children Aged 6-12 Years in Debre Tabor Town, South Gondar, Ethiopia
}

Hiwot Yisak ( $\sim$ hyisak@yahoo.com )

Debre Tabor University https://orcid.org/0000-0003-2922-289X

Melaku Tadege

Debre Tabor University

Birhanie Ambaw

Debre Tabor University

Amien Ewunetei

Debre Tabor University

\section{Research}

Keywords: Wasting, Stunting, Underweight, School age children, Debre Tabor, Ethiopia

Posted Date: September 30th, 2020

DOI: https://doi.org/10.21203/rs.3.rs-80614/v1

License: (c) (i) This work is licensed under a Creative Commons Attribution 4.0 International License.

Read Full License 


\section{Abstract}

Aim: Underweight, wasting and stunting are the commonest nutritional disorders among school age children especially in developing countries. This public health significant problem impairs the intellectual development of a child. The aim of this study was assessment of the Prevalence and Determinant factors of under nutrition among school age children aged 6-12 years

Methods: A cross sectional study was conducted in Debre Tabor town elementary schools among 314 school age children. The sample was allocated to all elementary schools proportionally to their number of school age children aged 6-12 years in 2018. WHO Antro- Plus was used to build Z-scores from anthropometric measurement. The data were analyzed by SPSS Version 20 . The degrees of association between dependent and independent variables was assessed using OR and 95\% Confidence interval during logistic regression. P-value less than 0.05 was considered statistically significant.

Results: Of the total study participants, $232(77.3 \%)$ were from public schools. The mean \pm standard deviation (SD) of height of children was $132.915 \pm 9.824 \mathrm{~cm}$ and the mean \pm standard deviation (SD) weight of children was $27.65 \pm 5.785 \mathrm{Kg}$. The prevalence of stunting, wasting and underweight was $11 \%$, $6.3 \%$, and $11.4 \%$ respectively. Students who ate their breakfast rarely were 8 times more likely to be underweight than those who ate their breakfast always (AOR $=7.9495 \% \mathrm{Cl}, 4.82-14.80$ ). Those who were sick were more likely to be underweight than their counterparts $\mathrm{AOR}=7.3,95 \% \mathrm{Cl}, 2.8-14.4)$. Those who never consume milk or milk products were $6.5(\mathrm{AOR}=6.5,95 \% \mathrm{Cl}, 1.7-23)$ times more likely to be stunted than those who consumed always. Sickness in the past two weeks was significantly associated with thinness $(\mathrm{AOR}=6.93,95 \% \mathrm{Cl}, 4.12-10.06)$.

Conclusions: The overall prevalence of wasting, stunting, and underweight was mild public health problem in this study.

\section{Background}

Malnutrition includes both under nutrition and over nutrition. Underweight, wasting and stunting are categorized as under nutrition. Under nutrition might happen either due to long -term or short -term inadequate nutrient intake. In addition, it can also be caused by food unavailability or increased disease prevalence [1]. Anthropometry is a universally applicable method to assess nutritional status in resource limited areas [2] .

According to World Health Organization (WHO), school age comprises the age between 6 to 12years; and it is a pre adolescent time. School age children are affected by different nutritional and health problems due to high demand (requirement) for the rapid growth rate and high engagement in physical activity [3]. So, adequate dietary intake is important for the physical and mental development during the primary school years [1]. 
Due to malnutrition there is high rate of morbidity and mortality of children in developing countries. Because of Malnutrition, the cognitive function will be affected, and impaired .Finally this may affect the economy of the household, the community and the nation at large[3, 4] .

Children gain up to $50 \%$ of their adult weight, $20 \%$ of their adult height and $50 \%$ of their adult skeletal mass during school age. Thus being malnourished in this age exposes them to serious short and long term health problems [5] .

Height has been found to be related to productivity, and 1\% loss in adult height as a result of childhood stunting is associated with a $1.4 \%$ loss in productivity. Improved nutrition and health improves the mental and physical capabilities of children and thereby their future earning capacity [6] .

On the other hand, improved nutrition and health to children have long been recognized as fundamental human rights. For example, in one of the conventions that Ethiopia has ratified, we find the following: "States parties recognize the right of the child to the enjoyment of the highest attainable standard of health....... and shall take appropriate measures "to combat disease and malnutrition...through the provision of adequate nutritious foods and clean drinking water..." and, "health care". Moreover, it is stated in the National Nutrition Strategy document. The right to the determinants of adequate nutrition is also upheld in the constitution of Ethiopia, entrusting the government to take appropriate measures to ensure that these rights are adequately protected, especially among the most vulnerable groups [7].

For the control of malnutrition a variety of actions are needed, such as agricultural interventions, provision of safe drinking water and sanitation, education and health services. As part of the Government's strategy to increase school enrollment and reduce drop-out rates in drought-prone areas of Ethiopia, the Ministry of Education, with support from WFP, began a project called "Improving Education through School Feeding" on a pilot basis in 1994 and currently WFP is actively working to alleviate malnutrition of school age children and increasing school attendance. This program enroll 102,000 primary school children, in the highly food insecure areas of Tigray, Afar, Amhara and Oromia Regions [8]

Several studies have investigated nutritional status of school age children in different parts of the world. However, data on the growth of school-age children, generated in a consistent manner across countries and over time, is difficult to find [9]. Lack of current reports on the prevalence of nutritional status in different areas of a given country may limit the rate at which decisions are made for intervention measures against these effects by concerned bodies such as National Government and International Organizations [10].

In Ethiopia and particularly in the study area, even though many studies have been carried out on malnutrition of less than five years old children, there is no study conducted so far on assessment of nutritional status and the determinants among school age children. Therefore, this study aimed to assess the school age nutritional status and its associated factors in Debre Tabor town. 


\section{Methods And Materials}

\section{Study Area}

The study was conducted in Debre Tabor Town, South Gondar Zone, in North West Ethiopia. The Town is located about 103 kilometers to the South east of Gondar and 50 kilometers east of Lake Tana, this historic town has a latitude and longitude of $11^{\circ} 51^{\prime} \mathrm{N} 38^{\circ} 1^{\prime} \mathrm{E}$ with an elevation of 2,706 meters above sea level. Based on the 2007 national census conducted by the Central Statistical Agency of Ethiopia (CSA), this town has a total population of 55,596, of whom 27,644 are men and 27,952 women. The majority of the inhabitants practiced Ethiopian Orthodox Christianity, with $96.72 \%$ reporting that as their religion, while $2.54 \%$ of the populations were Muslims. There are 10 elementary schools in the town among which six are private and the rest four (Tabor primary school, Gafat primary school, Tewodros II primary school and Hidar 11 primary school) are public.

\section{Study design and Period}

A school based cross sectional study was conducted from October to November, 2018.

\section{Study Population}

All children aged between 6-12 years who were attending elementary school at the time of data collection were included into this study but children having visible physical deformity, and didn't live in Debre Tabor Town was excluded.

\section{Sample size determination}

The sample size was estimated using the single population proportion formula by using confidence level of $95 \%(z=1.96)$, marginal error of $5 \%$, and proportions of stunting, wasting, and underweight. According to 2007 Ethiopia Demographic Health Survey, the prevalence of stunting, wasting, and underweight was $22.3 \%, 17.9 \%, 23.1 \%$ respectively [11]. Among the calculated sample size, the highest sample size was from underweight (273). Then, the final sample size was 314 after adding $15 \%$ of none response rate.

\section{Sampling techniques}

In order to select a representative sample of school age children from elementary schools of the Town, all of elementary schools found in the town were included. In each school a list of children was prepared to have sampling frame of students aged between 6-12 years. The calculated sample was allocated to each school proportionally based on their respective number of school age children in 2018 academic year. Then, a sample from each school was selected by simple random sampling (by random table method) from a list of frame of students belonging to the age group 6-12 years old.

\section{Data collection instruments}

A semi Structured questioner was developed after thorough review of different literatures. A height measuring length board which has a scale and sliding head piece and having 2 meters measuring capacity, with a precision of $0.1 \mathrm{~cm}$ was used for measuring the height and UNICEF's digital weighting 
scale (SECA) which has a capacity of $150 \mathrm{~kg}$ and with a precision of $0.1 \mathrm{kgwas}$ used for measuring weight.

\section{Data collection procedure}

Ten diploma nurses were recruited for data collection and 2 BSC nurses were recruited as supervisor. From each school, two teachers were assigned to facilitate, organize, and avail the study subjects when needed for interview and examination.

Questions were grouped and arranged according to particular objective that they should address. The questionnaire was originally developed in English and was translated to local language (Amharic). The questionnaire was pretested in Gasay Primary School (out of the study area). Then, appropriate modifications and corrections were done to before data collection. First, school administrators were contacted and then after, they gave permission to include into this study. Then children's were requested to bring their parents/caregivers to the school to get written informed consent and to collect relevant data. Then, data related to socio demographics, socio-economic, dietary intake and hygiene were collected from parents and care givers. Also, Anthropometric measurement of height and weight was done. Weights were taken using a digital portable weighing calibrated SECA scale to the nearest $0.1 \mathrm{~kg}$ and the height was measured by using a length board to the nears $0.1 \mathrm{~cm}$ in Frankfurt position. The school children were weighed after having lightly clothed/with school uniforms, without shoes and with empty pockets. Height was measured standing position.

\section{Data quality assurance}

Three days of training was provided to data collectors and supervisors. Data was collected under the supervision of the principal investigator and supervisors. Incomplete questionnaires were completed by making second visits to the schools. Pretesting was conducted and the questionnaire was adjusted accordingly. The data collectors were also trained on anthropometric measuring tools, how to consent the study participants, and ways of anthropometrical data measurement to maintain the uniformity of measurements. Weighing scale was calibrated to the zero before taking every measurement to reduce errors. Weight and height measurement was done twice and the average value was used for the analysis. Standardization test was conducted during training.

\section{Data processing and analysis}

After data collection was completed, the data were checked for completeness and then recode and categorization was done. Software program WHO Antro Plus was used to convert nutritional data from anthropometric measurement into Z-scores of the indices; $\mathrm{H} / \mathrm{A}, \mathrm{W} / \mathrm{H}$ and W/A taking age and sex into consideration using WHO reference curve. EPI-info Version 3.5.2 was used to enter the anthropometric and other data and then, the data was exported to SPSS Version 20 software for windows to conduct further descriptive and analytical analysis. Variable having $p$ - value of $<0.2$ in the bivariable logistic regression were entered into multivariable logistic regression analysis. The degrees of association 
between dependent and independent variables was assessed using OR and $95 \% \mathrm{Cl}$ was done. Finallyvalue $<0.05$ was used to declare statistical significance.

\section{Operational definition}

Nutritional status $=$ Refers to the physical of a child in weight and height.

Malnutrition = Refers to under nutrition that include wasting, Stunting and underweight.

Stunting $=$ If the child's Height for age Z scores of $<-2$ SD of the median WHO reference values.

Underweight: if the child's weight for age Z score is<-2 SD from the median WHO reference values.

Wasting: if the child weight for height Z score is<-2SD from the median WHO reference values.

\section{Results}

Data was collected from 300 students; 232(77.3\%) were from public schools. One hundred fifty nine (53\%) of children were females. Two hundred ninety nine (99.7\%) of the students were Amhara in ethnicity. Religion wise, 296(98.7\%) of them were Orthodox Christianity followers. From a total, $130(43.3 \%)$ of them were in birth order of $2-3$. The mean age \pm standard deviation (SD) of children was $9.9867 \pm 1.47663$ months.

Regarding to family size, $220(73.3 \%)$ of children live in a family size of 5 and above. Two hundred nine $(69.7 \%)$ of children live with both mother and father and about $83(27.7 \%)$ mothers of school age children cannot read and write as shown in the table below (Table 1). 
Table 1

Socio-demographic and socio economic status of School Age Children aged 6-12 Years in Debre Tabor Town elementary Schools, South Gondar, Ethiopia, $2018(n=300)$.

\begin{tabular}{|c|c|c|c|}
\hline \multicolumn{2}{|l|}{ Variables } & \multirow{2}{*}{$\begin{array}{l}\text { Frequency } \\
1 \\
\end{array}$} & \multirow{2}{*}{$\begin{array}{l}\text { Percentage } \\
.3\end{array}$} \\
\hline Age of the student & 6 & & \\
\hline & 7 & 16 & 5.3 \\
\hline & 8 & 45 & 15.0 \\
\hline & 9 & 32 & 10.7 \\
\hline & 10 & 91 & 30.3 \\
\hline & 11 & 60 & 20.0 \\
\hline & 12 & 55 & 18.3 \\
\hline \multirow[t]{4}{*}{ Birth order } & 1 & 99 & 33.0 \\
\hline & $2-3$ & 130 & 43.3 \\
\hline & $4-5$ & 47 & 15.7 \\
\hline & 6 and above & 24 & 8.0 \\
\hline \multirow[t]{6}{*}{ Educational status of the mother } & cannot read and write & 83 & 27.7 \\
\hline & can read and write & 28 & 9.3 \\
\hline & grade $1-4$ & 26 & 8.7 \\
\hline & grade $5-8$ & 59 & 19.7 \\
\hline & grade $9-12$ & 39 & 13.0 \\
\hline & above12 & 65 & 21.7 \\
\hline \multirow[t]{6}{*}{ Occupation of mothers } & house wife & 139 & 46.3 \\
\hline & Farmer & 4 & 1.3 \\
\hline & Merchant & 53 & 17.7 \\
\hline & government employee & 71 & 23.7 \\
\hline & daily labourers & 29 & 9.7 \\
\hline & Others & 4 & 1.3 \\
\hline \multirow[t]{3}{*}{ Age of the mother/caregivers } & below 25 & 7 & 2.3 \\
\hline & $25-29$ & 39 & 13.0 \\
\hline & $30-34$ & 92 & 30.7 \\
\hline
\end{tabular}




\begin{tabular}{|c|c|c|c|}
\hline \multicolumn{2}{|l|}{ Variables } & \multirow{2}{*}{$\begin{array}{l}\text { Frequency } \\
90\end{array}$} & \multirow{2}{*}{$\begin{array}{l}\text { Percentage } \\
30.0\end{array}$} \\
\hline & $35-39$ & & \\
\hline & $40-44$ & 33 & 11.0 \\
\hline & $45-49$ & 17 & 5.7 \\
\hline & $50-54$ & 11 & 3.7 \\
\hline & 55 and above & 7 & 2.3 \\
\hline \multirow[t]{6}{*}{ Educational status of the father } & cannot read and write & 34 & 11.3 \\
\hline & read and write & 39 & 13.0 \\
\hline & $1-4$ & 19 & 6.3 \\
\hline & $5-8$ & 57 & 19.0 \\
\hline & $9-12$ & 42 & 14.0 \\
\hline & 12 and above & 87 & 29.0 \\
\hline \multirow[t]{3}{*}{ Monthly income } & $<1500$ & 68 & 22.7 \\
\hline & $1500-3000$ & 126 & 42.0 \\
\hline & $>3000$ & 105 & 35.0 \\
\hline
\end{tabular}

\section{Dietary habit and water sources of households of school age children}

Regarding to dietary habit, the staple food among $268(89.3 \%)$ of households was Teff and $278(92.7 \%)$ of children were never been hungry in the past one month. One hundred sixty three (54.3\%) of children ate three times per day. And 144(48\%) of children ate breakfast always; $129(43 \%)$ of them ate some times; $26(8.7 \%)$ eat rarely and1 $(0.3 \%)$ almost never ate breakfast. One hundred forty two (47.3\%) children eat fruits once per week and 104(34.7\%) of children never consumed milk or milk product (Table 2).

Of all household food sources, $271(90.3 \%)$ of them were got by purchasing from market; $14(4.7 \%)$ from their own product; $12(4 \%)$ both from their own product and purchasing and $2(0.7 \%)$ get from aid. Two hundred eighty eight (96\%) of them were had a latrine at their home. from the total, $267(89 \%)$ of households do not treat drinking water and from these, the source of drinking water for $258(86 \%)$ of households were tap water. 
Table 2

Dietary habits of school age children Aged 6-12 years in Debre

Tabortown elementary schools, South Gondar, Ethiopia, 2018( $n=300)$.

\begin{tabular}{|llll|}
\hline Variables & & Frequency & Percentage \\
\hline Meal frequency & Once & 3 & 1.0 \\
\cline { 2 - 4 } & Twice & 24 & 8.0 \\
\cline { 2 - 4 } Fruit eating frequency & Three & 163 & 54.3 \\
\cline { 2 - 4 } & 4 and above & 110 & 36.7 \\
\cline { 2 - 4 } & not at all & 55 & 18.3 \\
\cline { 2 - 4 } & Once & 142 & 47.3 \\
\cline { 2 - 4 } Milk consumption & Twice & 63 & 21.0 \\
\cline { 2 - 4 } & $\geq$ Three & 40 & 13.3 \\
\cline { 2 - 4 } & Never & 104 & 34.7 \\
\cline { 2 - 4 } & Sometimes & 95 & 31.7 \\
\cline { 2 - 4 } & Most of the days & 35 & 11.7 \\
\cline { 2 - 4 } & Always & 66 & 22.0 \\
\cline { 2 - 4 } & & &
\end{tabular}

\section{Sanitation and Hygienic practice}

Concerning to hand washing habit $236(78.7 \%)$ of school age children always wash their hands before eating. From all children, 203(67.7\%) of them were using soap sometimes. One hundred fifty three (51\%) children wash unpeeled fruits sometimes before eating (Table 3 ) 
Table 3

Sanitation and hygiene status of school age children aged 6-12 Years in Debre Tabor town elementary schools, South Gondar, Ethiopia $(n=300)$

\begin{tabular}{|c|c|c|c|}
\hline Variables & & Frequency & Percentage \\
\hline \multirow[t]{8}{*}{ Waste disposal system } & Collection by municipality & 50 & 16.7 \\
\hline & Burial & 80 & 26.7 \\
\hline & private collector & 24 & 8.0 \\
\hline & thrown on the road or free space & 20 & 6.7 \\
\hline & collected in the compound & 5 & 1.7 \\
\hline & thrown on the farm place & 5 & 1.7 \\
\hline & Burned & 114 & 38.0 \\
\hline & Others & 2 & .7 \\
\hline \multirow[t]{5}{*}{ Hand washing habit } & Never & 3 & 1.0 \\
\hline & Rarely & 4 & 1.3 \\
\hline & some times & 28 & 9.3 \\
\hline & Most of the days & 29 & 9.7 \\
\hline & Always & 236 & 78.7 \\
\hline \multirow[t]{5}{*}{ Soap usage while hand washing } & Never & 18 & 6.0 \\
\hline & Rarely & 29 & 9.7 \\
\hline & Sometimes & 203 & 67.7 \\
\hline & Most of the days & 16 & 5.3 \\
\hline & Always & 34 & 11.3 \\
\hline \multirow[t]{4}{*}{ Washing unpeeled fruits } & Never & 26 & 8.7 \\
\hline & Sometimes & 153 & 51.0 \\
\hline & Most of the days & 24 & 8.0 \\
\hline & Always & 97 & 32.3 \\
\hline
\end{tabular}

Fifty eight (19.3/\%) of children have been sick in the past two weeks prior to data collection. The cause of sickness was stomach ache 25(27.6\%) followed by common cold 12(20.7\%). 
The mean \pm standard deviation (SD) of height of children was $132.915 \pm 9.824 \mathrm{~cm}$ and the mean \pm standard deviation (SD) of weight of children was $27.65 \pm 5.785 \mathrm{Kg}$.In this study, $21(11.4 \%, 95 \% \mathrm{Cl}, 6.8-$ $15.9)$ of children aged $6-10$ years were under weight. Thirty three $(11 \%, 95 \% \mathrm{Cl}, 7.3-15)$ of all children were stunted; $19(6.3 \%, 95 \% \mathrm{Cl}: 3.5,9.3)$ of children were wasted. Over all, the likely to have severe form of malnutrition was rare among these age groups in the study area.

\section{Factors associated with under nutrition.}

\section{Factors associated with underweight}

In the bi-variable analysis sex of the student, educational status of their fathers, breakfast eating habit, milk consumption, treating water and sickness in the past two weeks were associated with underweight. All these variables were fitted into multivariable logistic regression analysis. Then, educational status of the father, children's breakfast eating habit, consumption of milk, and having sickness in the past 2 weeks were significant variables.

Here, educational status of a father being grade 9-12 was protective factor for not to be underweight as compared to fathers who cannot read and write $(A O R=0.09 ; 95 \% \mathrm{Cl}, 0.01-0.94)$. Students who rarely ate their breakfast were more likely to be underweight than those who eat breakfast always (AOR = $7.94 ; 95 \% \mathrm{Cl}, 4.82-14.80)$. Those who never consumed milk or milk products were more likely to be underweight as compared to those who consumed always ( $\mathrm{AOR}=5.46 ; 95 \% \mathrm{Cl}, 4.02-6.90)$. In addition, those who were sick two weeks before data collection were more likely to be underweight than their counterparts $(\mathrm{AOR}=7.3 ; 95 \% \mathrm{Cl}, 2.8-14.4)($ Table 4$)$. 
Table 4

Factors associated with underweight among School Age Children Aged 6-12 Years in Debre Tabor town elementary Schools, South Gondar, Ethiopia

\begin{tabular}{|c|c|c|c|c|}
\hline Variables & & $\operatorname{COR}(95 \% \mathrm{Cl})$ & AOR(95\% C.I) & $\begin{array}{l}P \\
\text { value }\end{array}$ \\
\hline \multirow[t]{6}{*}{$\begin{array}{l}\text { Educational status of the } \\
\text { father }\end{array}$} & $\begin{array}{l}\text { Cannot read and } \\
\text { write }\end{array}$ & & & \\
\hline & read and write & $0.43(0.07-2.80)$ & $0.3(0.24-8.31)$ & .357 \\
\hline & $1-4$ & $0.75(0.12-4.75)$ & $0.22(.02-2.39)$ & .214 \\
\hline & $5-8$ & $0.38(0.03-4.12)$ & $0.24(0.01-9.07)$ & .441 \\
\hline & $9-12$ & $0.22(0.05-0.97)$ & $0.09(.01-0.95)$ & .045 \\
\hline & 12 and above & $0.41(0.08-2.19)$ & $0.45(0.04-4.76)$ & .506 \\
\hline \multirow[t]{2}{*}{ Sex of the student } & Male & & & \\
\hline & Female & $0.45(0.17-1.18)$ & $1.30(0.31-5.53)$ & .720 \\
\hline \multirow[t]{3}{*}{ Breakfast eating habit } & Rarely & $\begin{array}{l}12.60(3.14- \\
50.02)\end{array}$ & $\begin{array}{l}7.94(4.82- \\
14.80)\end{array}$ & .002 \\
\hline & Some times & $\begin{array}{l}10.44(2.99- \\
36.01)\end{array}$ & $\begin{array}{l}13.40(1.70- \\
15.38)\end{array}$ & .014 \\
\hline & Always & & & \\
\hline \multirow[t]{4}{*}{ Milk consumption } & never & $\begin{array}{l}13.11(2.90- \\
16.78)\end{array}$ & $5.46(4.03-6.96)$ & .002 \\
\hline & Some times & $\begin{array}{l}13.30(1.69- \\
15.39)\end{array}$ & $5.85(2.26-9.31)$ & .013 \\
\hline & Most of the days & $\begin{array}{l}63.21(0.01- \\
71.24)\end{array}$ & $16(0.01-22.86)$ & .998 \\
\hline & Always & & & \\
\hline \multirow[t]{2}{*}{ Water treatment } & yes & & & \\
\hline & no & $0.32(0.10-1.01)$ & $\begin{array}{l}7.44(0.71- \\
77.97)\end{array}$ & .094 \\
\hline \multirow[t]{2}{*}{$\begin{array}{l}\text { Sickness in the past two } \\
\text { weeks }\end{array}$} & Yes & $\begin{array}{l}13.50(11.01- \\
23.54\end{array}$ & $\begin{array}{l}7.32(2.87- \\
14.41)\end{array}$ & .002 \\
\hline & no & & & \\
\hline
\end{tabular}


Variables having a $\mathrm{p}$ value of $<0.2$ in the bivariable analysis are eating frequency per day, milk consumption habit, soap usage for hand washing and washing of unpeeled fruits before eating. In multivariable analysis those who never consume milk or milk products are more likely to be stunted than those who consumed always (AOR $=6.5 ; 95 \% \mathrm{Cl}, 1.7-23)$ and those who never use soap for hand washing are more likely to be stunted than those who used soap always ( $A O R=4.5 ; 95 \% \mathrm{Cl}, 1.7-12)$. 
Table 5

Factors associated with stunting among School Age Children Aged 6-12 Years in Debre Tabor town elementary Schools, South Gondar, Ethiopia

\begin{tabular}{|c|c|c|c|c|}
\hline & & COR $(95 \% \mathrm{Cl})$ & $\begin{array}{l}\text { AOR( } \\
\text { 95\% C.I.) }\end{array}$ & \\
\hline \multirow[t]{4}{*}{ Meal frequency per day } & Once & $3.5(0.24-5.14)$ & $\begin{array}{l}4.65(0.25- \\
16.14)\end{array}$ & .302 \\
\hline & Twice & $\begin{array}{l}3.57(0.31- \\
4.13\end{array}$ & $4.33(0.32-9.65)$ & .273 \\
\hline & Three times & $5.6(0.46-8.04)$ & $\begin{array}{l}6.456(0.45- \\
13.66)\end{array}$ & .172 \\
\hline & $>=4$ times & & & \\
\hline \multirow[t]{4}{*}{ Milk consumption habit } & Never & $\begin{array}{l}5.99(3.69- \\
11.65)\end{array}$ & $\begin{array}{l}6.49(1.76- \\
23.945)\end{array}$ & .005 \\
\hline & Some times & $\begin{array}{l}1.17(0.39- \\
3.45)\end{array}$ & $1.23(0.36-4.19)$ & .736 \\
\hline & $\begin{array}{l}\text { Most of the } \\
\text { days }\end{array}$ & $\begin{array}{l}1.42(0.57- \\
3.49)\end{array}$ & $1.63(.613-4.31)$ & .329 \\
\hline & Always & & & \\
\hline \multirow[t]{5}{*}{$\begin{array}{l}\text { How often you use soap during } \\
\text { hand washing }\end{array}$} & Never & $\begin{array}{l}6.12(0.71- \\
28.50)\end{array}$ & $\begin{array}{l}4.546(1.70- \\
12.14)\end{array}$ & .003 \\
\hline & Occasionally & $\begin{array}{l}10.08(9.21- \\
25.65)\end{array}$ & $\begin{array}{l}20.40(2.06- \\
28.24)\end{array}$ & .010 \\
\hline & Sometimes & $\begin{array}{l}3.29(1.35- \\
5.67)\end{array}$ & $\begin{array}{l}7.826(0.812- \\
75.48)\end{array}$ & .075 \\
\hline & $\begin{array}{l}\text { Most of the } \\
\text { time }\end{array}$ & $\begin{array}{l}2.52(0.48- \\
10.33)\end{array}$ & $\begin{array}{l}3.326(0.560- \\
19.76)\end{array}$ & .186 \\
\hline & Always & & & \\
\hline \multirow[t]{5}{*}{ Washing of unpeeled fruits } & Never & $2.8(0.35-5.41)$ & $\begin{array}{l}0.299(.033- \\
2.681)\end{array}$ & .281 \\
\hline & Occasionally & $3.42(0.36-8.7)$ & $\begin{array}{l}4.16(0.512- \\
16.71)\end{array}$ & 0.26 \\
\hline & Some times & $\begin{array}{l}0.15(0.02- \\
1.41)\end{array}$ & $0.13(0.01-1.38)$ & 0.091 \\
\hline & $\begin{array}{l}\text { Most of the } \\
\text { time }\end{array}$ & $\begin{array}{l}0.35(0.042- \\
2.85)\end{array}$ & $0.38(0.04-3.53)$ & 0.398 \\
\hline & Always & & & \\
\hline
\end{tabular}




\section{Factors associated with low BAZ}

In the bivariate analysis fruit eating frequency per week, milk consumption habit, and sickness in the past two weeks were associated with low BAZ or wasting. Finally in the multivariable analysis those who never consumed milk were more likely to be wasted than who consumed always, and sickness in the past two weeks is significantly associated with low BAZ (Table 6)

Table 6

Factors associated with wasting among School Age Children Aged 6-12 Years in Debre Tabor Town Glementary Schools, South Gondar, Ethiopia

\begin{tabular}{|c|c|c|c|c|}
\hline & & $\operatorname{coR}(95 \% \mathrm{Cl})$ & AOR (95\% C.I.) & $\begin{array}{l}\mathrm{P}- \\
\text { value }\end{array}$ \\
\hline \multirow[t]{4}{*}{ Milk consumption habit } & always & & & \\
\hline & $\begin{array}{l}\text { Most of the } \\
\text { days }\end{array}$ & $2.73(0.74-10.1)$ & $\begin{array}{l}2.39(0.455- \\
12.49)\end{array}$ & .304 \\
\hline & Some times & $2.15(0.46(10.12$ & $2.26(0.35-14.47)$ & .391 \\
\hline & never & $6.06(1.35-8.55)$ & $9.02(1.56-51.98)$ & .014 \\
\hline \multirow[t]{4}{*}{ Fruit eating pattern per week } & never & & & . \\
\hline & once & $\begin{array}{l}0.44(0.045- \\
4.43)\end{array}$ & $.591(.044-8.009)$ & .693 \\
\hline & twice & $(0.37-0.04-3.08)$ & $.226(.023-2.256)$ & .205 \\
\hline & $\begin{array}{l}\text { Three and } \\
\text { above }\end{array}$ & $0.19(0.24-2.10)$ & $.213(.019-2.443)$ & .214 \\
\hline \multirow{2}{*}{$\begin{array}{l}\text { Sickness in the past two } \\
\text { weeks }\end{array}$} & yes & $8.4(4.01-12.32)$ & $6.93(4.12-10.06)$ & .000 \\
\hline & No & & & \\
\hline
\end{tabular}

\section{Discussion}

This study showed that the prevalence of stunting, wasting and underweight were $11 \%, 6.3 \%$ and $11.4 \%$ respectively. In Ethiopia a Cross-sectional survey which was aimed at estimating the prevalence of chronic health and nutritional conditions of school age children in 2008 reported that the prevalence of stunting, wasting, and underweight were $22.3 \%, 17.9 \%$ and $23.1 \%$, respectively [11]. The report is higher than the finding of the current study. The reason might be, due to difference in geographic area i.e. the current study was conducted in a town and time difference. Another study on Prevalence and factors associated with stunting and thinness among school-age children in Arba Minch Health and Demographic Surveillance Site, Southern Ethiopia in 2016, showed prevalence of stunting and thinness were $41.9 \%$ (95\% Cl: $37-47)$ and $8.0 \%$ (95\% Cl: 5.4-10.8) respectively. This is also higher than the current study and the variation might be due to geographical difference and sample size difference [12]. 
Nutrition and infectious diseases are commonly shown to go hand in hand. There is a bidirectional influence in which malnutrition may predispose to infection or increase its severity, while infection itself results in nutritional abnormalities. In any population, the impact of malnutrition depends on the prevalence of infection, and the impact of infection depends upon the nutritional base [13]. As per the UNICEF's conceptual frame work of malnutrition, infection or disease is the immediate cause of malnutrition [9] .The finding of this study support this idea as sickness in the past two weeks was the best predictor of wasting.

In this study not eating breakfast was associated with underweight. In line with this, a study which assessed nutritional Status of primary school children \& their awareness in Slum areas of urban and rural areas in 2007 in Giza governorate of Egyptian showed that $76.9 \%$ of urban and $69.3 \%$ of rural children were underweight, $9.8 \%$ urban and $12.8 \%$ rural were stunted. $(P=<0.05)$ for both underweight and stunting. Only $33.9 \%$ of urban children and $29.3 \%$ of rural ones have eaten breakfast[14] .

In this study not using soap for hand washing was associated with stunting. But a case study in Bangladesh on underweight children showed that practice washing hands with soap and water after defecation was $23 \%$ more likely to reduce underweight [15].

The ability of each parent to obtain and use information about appropriate caring practices and health services for the child depends on their educational status. More education will consequently improve the mother's knowledge and health practices and have a greater impact on child nutrition. There are many study findings supporting the idea that 'when parents are more educated, their children are less likely to be malnourished [16-18].

In this study educational status of a father, was associated with underweight. In agreement with this, aStudy which was undertaken to determine the prevalence of underweight and stunting, and to assess the impact of some socio economic variables on under nutrition among school age children aged 613 years of age in West Bengal, India, in 2010 showed that underweight (WAZ) was significantly associated with fathers' educational status [16]. On the other hand, a study on assessment of Prevalence and risk factors for Stunting among school children and adolescents in Abeokuta, Southwest Nigeria found that from 570 children aged $7-13$ years, $17.4 \%$ children were stunted. Of the stunted children, $22.2 \%$ were severely stunted. Low maternal education (odds ratio $=2.4 ; 95 \%$ confidence interval $1.20-4.9$; $p=0.015)$ was the major contributory factor to stunting [19] .

In this study milk consumption status was significantly associated with low BAZ, Stunting and Underweight. In line with this, a cross-sectional study of malnutrition and associated factors among school aged children in rural and urban settings of Fogera and LiboKemkem Districts, Ethiopia, in 2012 reported that thinness was statistically associated with consumption of food from animal sources (OR = $0.26 ; 95 \% \mathrm{Cl}, 0.10-0.67)[20]$.

\section{Conclusion}


In this study, the magnitude of stunting, wasting and underweight was a mild public health problem. Stunting among school age children was statistically associated with consumption of milk or milk products and use of soap for hand washing. The rate of wasting among school age children was statistically associated with consumption milk and sickness in the past two weeks. The magnitude of underweight among school age children was statistically associated with the educational status of the father, children's breakfast eating habit, consumption of milk, and having sickness in the past 2 weeks. Introducing interventions aiming at improving the living standard like water source hygienic practice, intake of milk and milk products and dietary diversity practice could improve the nutritional status of the school age children in addition to socio-demographic factors.

\section{List Of Abbreviations}

AOR: Adjusted Odd Ratio

BAZ: Body mass index for age $Z$ score

BMI: Body Mass Index

Cl: Confidence Interval

COR: Crude Odd Ratio

EDHS: Ethiopian Demographic Health Survey

H/A: Height for Age

HAZ: Height for Age Z score

NCHS: National Centre for Health Statistics

OR: Odds Ratio

SD: Standard Deviation

SPSS: Statistical Package for Social Science

SPSS: Statistical Package for Social Sciences

UNICEF: United National International Children's Fund

W/A: Weight for Age

WAZ: weight for age Z score

WFP: World Food Program 


\section{Declarations}

\section{Ethical approval and consent to participate}

Ethical clearance was obtained from the Debre Tabor University Ethical Review committee. A permission letter was received from the respective elementary schools. Written informed consent was obtained from each study participant parents/caregivers after explaining the purpose of the study. The right of a participant to withdraw from the study at any time, without any precondition was disclosed unequivocally. Moreover, the confidentiality of information obtained was guaranteed by all data collectors and investigators using code numbers and by keeping the questionnaire locked. The weight and height were measured in private rooms. Nutrition education and counseling were provided to all study participants after the data collection process completed.

\section{Consent for publication}

Not applicable

\section{Availability of data and materials}

The datasets used and/or analyzed during the current study are available from the corresponding author on reasonable request.

\section{Conflict of interest}

We authors declared that there is no any computing interest

\section{Financial support}

There was no financial support for this study

\section{Authors' contribution}

HY; conceptualize the study, writing the proposal, designed the study, carried out statistical analysis, and writing this manuscript.

MT, BA, and AE: participated in the proposal writing, designed the study, statistical analysis, reviewing, and approval.

Finally, all the authors read, comment, and approved this manuscript before sending it for publication.

\section{Acknowledgment}


The authors would like to express our sincere gratitude to those study participants for their willingness to participate in this study. The authors also thank the Debre Tabor University for supporting this study.

\section{References}

1. Nandy, S., et al., Poverty, child undernutrition and morbidity: new evidence from India. Bulletin of the World Health Organization, 2005. 83: p. 210-216.

2. Status, W.P., The use and interpretation of anthropometry. WHO technical report series, 1995. 854(9).

3. Organization, W.H., School policy framework: implementation of the WHO global strategy on diet, physical activity and health. 2008: World Health Organization.

4. Abudayya, A., et al., Overweight, stunting, and anemia are public health problems among low socioeconomic groups in school adolescents (12-15 years) in the North Gaza Strip. Nutrition research, 2007. 27(12): p. 762-771.

5. Gaur, R., G. Boparai, and K. Saini, Effect of under-nutrition on permanent tooth emergence among Rajputs of Himachal Pradesh, India. Annals of human biology, 2011. 38(1): p. 84-92.

6. Ethiopia, T.F.D.R.o., Welfare Monitoring Survey (WMS), 2004,Analytical Report. , in 2004, Central Statistical Authority Addis Ababa.

7. ofEthiopia, T.F.D.R., National Nutrition Strategy, F.M.o. Health., Editor. January 2008: Addis Ababa.

8. Kraemer, K.a.Z., Nutritional Anemia. 2007, Sight and Life press: Switzerland. p. 1- 400.

9. (UNICE).2003., U.N.C.s.F., Policy Review: Strategy for Improved Nutrition of children and Women in Developing Countries. New York USA: UNICEF., 2003.

10. Brooker, S., A.C. Clements, and D.A. Bundy, Global epidemiology, ecology and control of soiltransmitted helminth infections. Advances in parasitology, 2006. 62: p. 221-261.

11. Hall, A., et al., National survey of the health and nutrition of schoolchildren in Ethiopia. Tropical Medicine \& International Health, 2008. 13(12): p. 1518-1526.

12. Tariku, E.Z., et al., Prevalence and factors associated with stunting and thinness among school-age children in Arba Minch Health and Demographic Surveillance Site, Southern Ethiopia. PLoS One, 2018. 13(11): p. e0206659.

13. Brundtland, G.H., Nutrition and infection: malnutrition and mortality in public health. Nutr Rev, 2000. 58(2 Pt 2): p. S1-4; discussion S63-73.

14. Emam, S., et al., Assessment of nutritional status of some primary school children \& their awareness in slum areas. Alexandria Journal of Pediatrics, 2005. 19(1): p. 113-119.

15. Karim, R., MD. Nazrul Islam Khan, M.Akhtaruzzaman Nutritional Status of Young Children in a Bangladesh National Nutrition Program Area,' A Case Study. , T.B.D. Studies., Editor. 2008.

16. Mondal, P.R., S. Biswas, and K. Bose, Gender discrimination in undernutrition with mediating factors among Bengalee school children from Eastern India. Homo, 2012. 63(2): p. 126-35.

17. Sánchez-Pérez, H.J., et al., Malnutrition among children younger than 5 years-old in conflict zones of Chiapas, Mexico. Am J Public Health, 2007. 97(2): p. 229-32. 
18. Joshi HS, G.R., Joshi M C, MahajanVipul Determinants of Nutritional Status of School Children - A Cross Sectional Study in the Western Region of Nepal. Nutritional Journal of IRM, 2011. Vol. 2(1).

19. Senbanjo, I.O., et al., Prevalence of and risk factors for stunting among school children and adolescents in Abeokuta, southwest Nigeria. J Health Popul Nutr, 2011. 29(4): p. 364-70.

20. Herrador, Z., et al., Cross-sectional study of malnutrition and associated factors among school aged children in rural and urban settings of Fogera and Libo Kemkem districts, Ethiopia. PLoS One, 2014. 9(9): p. e105880. 